\title{
Rapid and efficient detection methods of pathogenic swine enteric coronaviruses
}

\author{
Yuguang $\mathrm{Fu}^{1} \cdot$ Baoyu $\mathrm{Li}^{1} \cdot$ Guangliang Liu ${ }^{1}$ (1) \\ Received: 4 March 2020 / Revised: 18 April 2020 / Accepted: 26 April 2020 / Published online: 19 May 2020 \\ (C) Springer-Verlag GmbH Germany, part of Springer Nature 2020
}

\begin{abstract}
Porcine enteric coronaviruses (CoVs) cause highly contagious enteric diarrhea in suckling piglets. These COV infections are characterized by clinical signs of vomiting, watery diarrhea, dehydration, and high morbidity and mortality, resulting in significant economic losses and tremendous threats to the pig farming industry worldwide. Because the clinical manifestations of pigs infected by different $\mathrm{CoVs}$ are similar, it is difficult to differentiate between the specific pathogens. Effective high-throughput detection methods are powerful tools used in the prevention and control of diseases. The immune system of piglets is not well developed, so serological methods to detect antibodies against these viruses are not suitable for rapid and early detection. This paper reviews various PCR-based methods used for the rapid and efficient detection of these pathogenic CoVs in swine intestines.
\end{abstract}

\section{Key points}

1. Swine enteric coronaviruses (CoVs) emerged and reemerged in past years.

2. Enteric CoVs infect pigs at all ages with high mortality rate in suckling pigs.

3. Rapid and efficient detection methods are needed and critical for diagnosis.

Keywords RT-PCR, detection methods $\cdot$ Swine Diarrhea $\cdot$ Pathogenic enteric coronaviruses

\section{Introduction}

The coronaviruses (CoVs) critically threaten human and animal health because infection with them results in respiratory or enteric tract diseases (Woo et al. 2012). For instance, pneumonia occurs in humans infected with the new $\mathrm{CoV}$ that emerged in China in the middle of Dec. 2019; the virus has subsequently spread to many countries worldwide where it threatens the health of humans, resulting in tremendous economic losses. CoVs are enveloped, positive-sense, singlestranded RNA viruses that possess a genome ranging from 25.4 to $31.7 \mathrm{~kb}$; they belong to the order Nidovirales, family

Guangliang Liu

LiuGuangliang01@ caas.cn

1 State Key Laboratory of Veterinary Etiological Biology, Lanzhou Veterinary Research Institute, Chinese Academy of Agricultural Sciences, Lanzhou 730046, China
Coronaviridae, and subfamily Coronavirinae (Woo et al. 2012). Based on antigenic relationships, the classification of coronaviruses was traditionally divided into 3 genera, but they were replaced by the following four genera: Alphacoronavirus (Alpha-CoV), Betacoronavirus (Beta-CoV), Gammacoronavirus (Gamma-CoV), and Deltacoronavirus (Delta-CoV), which are based on genetic and antigenic characteristics (Woo et al. 2010). Epidemiological surveys have indicated that bats and birds seem to be natural reservoirs for Alpha- and Beta-CoVs and Gamma- and Delta-CoVs, respectively (Bolles et al. 2011; Woo et al. 2012). CoVs in four genera have been verified in a variety of species, e.g., canines, felines, and birds (Chan et al. 2013).

Six CoVs have been identified in swine (Table 1): porcine epidemic diarrhea virus (PEDV), transmissible gastroenteritis virus (TGEV), swine acute diarrhea syndrome coronavirus (SADS-CoV), and porcine respiratory $\mathrm{CoV}(\mathrm{PRCoV})$ in the Alpha-CoV genus, porcine hemagglutinating encephalomyelitis virus (PHEV) in the Beta-CoV genus, and porcine 
Table 1 Relevant information of swine coronaviruses

\begin{tabular}{|c|c|c|c|c|}
\hline Viruses & Genus & $\begin{array}{l}\text { First } \\
\text { discovery }\end{array}$ & Tissue tropism & Clinical signs \\
\hline TGEV & $\alpha-\mathrm{CoV}$ & 1946 & Small intestines & Diarrhea, dehydration, weight loss \\
\hline PEDV & $\alpha-\mathrm{CoV}$ & 1977 & Small intestines & $\begin{array}{l}\text { Diarrhea, dehydration, weight loss, } \\
\text { death }\end{array}$ \\
\hline SADS-CoV & $\alpha-\mathrm{CoV}$ & 2017 & Small intestines & $\begin{array}{l}\text { Diarrhea, dehydration, weight loss, } \\
\text { death }\end{array}$ \\
\hline PRCoV & $\alpha-\mathrm{CoV}$ & 1984 & Respiratory tract & Coughing, mild fever, polypnea \\
\hline PHEV & $\beta-\mathrm{CoV}$ & 1957 & $\begin{array}{l}\text { Respiratory tract, central } \\
\text { nervous system }\end{array}$ & $\begin{array}{l}\text { Vomiting, wasting disease and/or } \\
\text { encephalomyelitis }\end{array}$ \\
\hline $\mathrm{PDCoV}$ & $\delta-\mathrm{CoV}$ & 2012 & Small intestines & $\begin{array}{l}\text { Diarrhea, dehydration, weight loss, } \\
\text { death }\end{array}$ \\
\hline
\end{tabular}

$T G E V$, transmissible gastroenteritis virus; $P E D V$, porcine epidemic diarrhea virus; $C o V$, coronavirus; $S A D S-C o V$, swine acute diarrhea syndrome coronavirus; $P R C o V$, porcine respiratory $\mathrm{CoV} ; P H E V$, porcine hemagglutinating encephalomyelitis virus; PDCoV, porcine deltacoronavirus; $\alpha$, alpha; $\beta$, beta; $\delta$, delta deltacoronavirus (PDCoV) in the Delta-CoV genus (Jung et al. 2016; Pan et al. 2017; Pensaert and de Bouck 1978; Woo et al. 2012; Zhang 2016; Zhou et al. 2018). Among the six swine CoVs, TGEV, PEDV, PDCoV, and SADS-CoV are enteric viruses that cause diarrhea in the pig population, resulting in significant economic losses and tremendous threats to the pig industry worldwide. The four swine enteric CoVs causing highly contagious enteric diarrhea in neonatal and suckling piglets are clinically characterized by vomiting, watery diarrhea, dehydration, and high morbidity and mortality (Gong et al. 2017; Hsu et al. 2018). Because the clinical signs of pigs infected by these CoVs are very similar (Table 1), it is difficult to differentiate the specific pathogens based on clinical symptoms. Effective high-throughput detection methods are needed for their differential determination and would represent powerful tools to prevent and control diseases.

As far as we know, many standard detection methods can be used to distinguish between causative agents, including virus isolation, electron microscopy, virus neutralization, and indirect immunofluorescence assays. However, these methods are time-consuming, laborious, and not suitable for the early and rapid detection of the four swine enteric CoVs (Carman et al. 2002; Dulac et al. 1977; van Nieuwstadt et al. 1988). The enzyme-linked immunosorbent assay is a powerful and highthroughput method for detecting specific antibodies, but the immune system of piglets is not well developed, so serological methods for detecting antibodies against these viruses are also not suitable for rapid and early detection. Polymerase chain reaction (PCR) methods have been widely used to detect pathogens since the PCR was invented; PCR has proven to be powerful and convenient tools for precise detection of diarrheal pathogens in pig populations (Ben Salem et al. 2010; Collins et al. 2008; Kim et al. 2007). This paper reviews various PCR-based methods for the rapid and efficient detection of these pathogenic CoVs in swine intestines.

\section{Pan-CoV RT-PCR assay for the detection of CoVs}

Figure 1 summarizes the basic workflow for the detection of the swine enteric coronaviruses from clinical samples. Generally, porcine fecal or intestinal samples need to be suspended and homogenized in sterile PBS and centrifuged to remove debris. The supernatant should be collected and filtered through a $0.45-\mu \mathrm{m}$ filter to remove the debris and some potential bacteria. The yield supernatant can be used to extract the total RNAs by Trizol reagent or RNA extraction kit. The total RNAs are used to reverse transcription by random primers to generate cDNA. This cDNA is employed as a template to do PCR amplification either by specific individual coronavirus or by pan-CoV primers first then followed by specific primers targeting individual swine enteric coronavirus when necessary. The PCR products are eventually subjected to DNA electrophoresis and analyzed under UV light to identify the desired bands.

The pan-CoV PCR method is a powerful tool for detecting all known and unknown CoVs; it is based on the conserved gene sequences among them (Moes et al. 2005). This assay is widely used to detect CoVs. Pan-CoV RT-PCR was employed to detect all known CoVs in the human respiratory tract (Vijgen et al. 2008) and to detect distinct Alpha-CoVs in five different bat species (Escutenaire et al. 2007; Lazov et al. 2018; Vijgen et al. 2008). For swine enteric CoVs, pan-CoV PCR also played an important role in identification. During the early stage of investigating cases of diarrhea in piglets in the USA caused by the PEDV variant and PDCoV, pan-CoV RT-PCR was applied to identify the causative agent together with electron microscopy and sequencing ( $\mathrm{Li}$ et al. 2014; Stevenson et al. 2013). In addition, during the identification of piglet diarrhea disease caused by SADS-CoV in China, pan-CoV RT-PCR was employed (Pan et al. 2017). In 2018, $\mathrm{Hu}$ et al. reported an improved one-step pan-CoV RT-PCR 


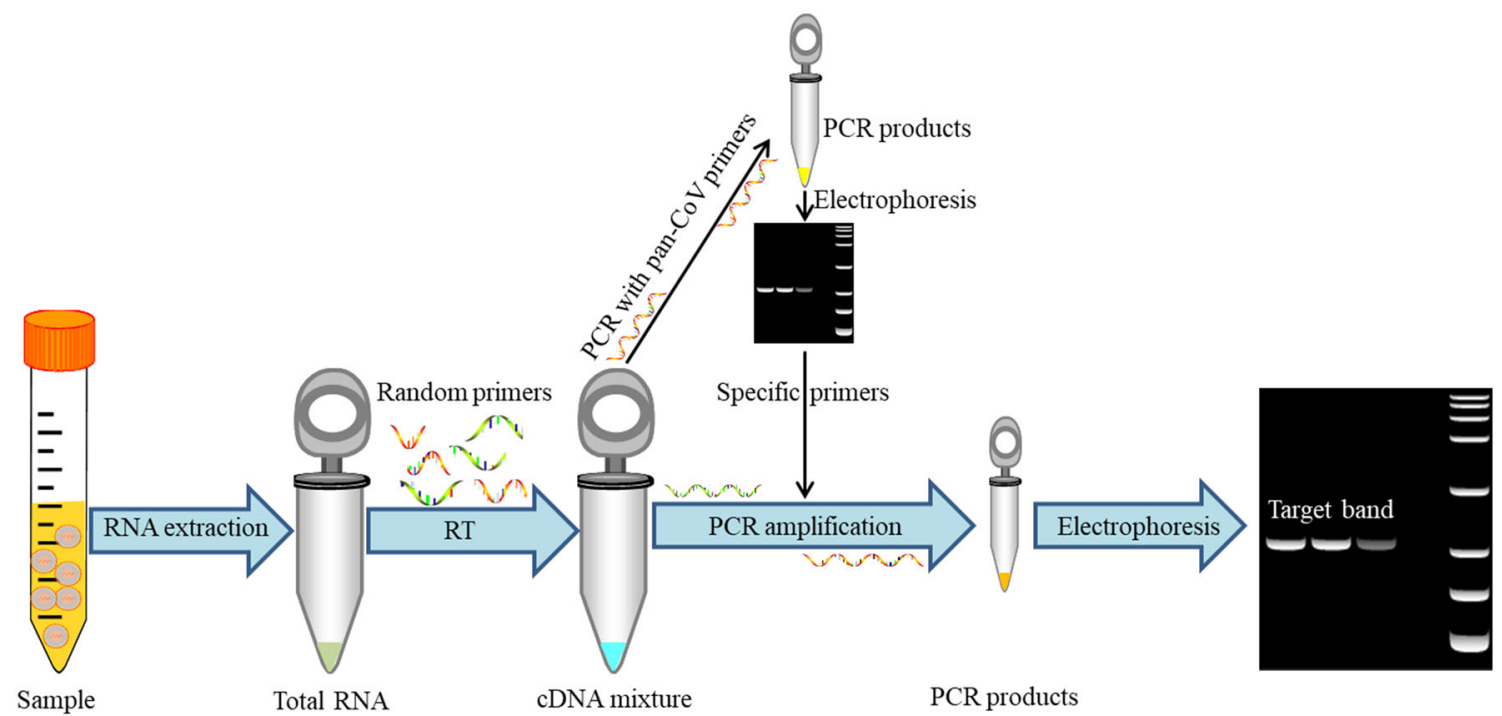

Fig. 1 The schematic diagram of the workflow for swine enteric coronavirus detection by RT-PCR. Porcine fecal or tissue samples are homogenized in sterile PBS and centrifuged to remove debris. The supernatant is filtered through a $0.45-\mu \mathrm{m}$ filter and used to total RNA extraction. The total RNAs are subjected to reverse transcription using random primer to generate cDNA. With this $\mathrm{cDNA}$ as template, the PCR

amplification is carried out either by specific individual coronavirus or by pan-CoV primers first then followed by specific primers targeting individual swine enteric coronavirus when necessary. The PCR products are subjected to DNA electrophoresis and observed under UV light to identify the desired bands

assay for the detection of known human and animal CoVs on the basis of the RNA-dependent RNA polymerase (RdRP) gene (Hu et al. 2018). Though pan-CoV PCR could detect all known CoVs in humans and animals, it could not make a differential detection, so it is not suitable for routine swine enteric $\mathrm{CoV}$ detection.

\section{PEDV detection by PCR-based methods}

Porcine epidemic diarrhea (PED) is an enteric disease caused by PEDV that can infect pigs of all ages with different levels of clinical signs of vomiting, diarrhea, dehydration, and weight loss, but the disease is much more severe in suckling piglets (Have et al. 1992; Shibata et al. 2000; Song and Park 2012; Sueyoshi et al. 1995). PED was first reported in England in 1971, but the PEDV was isolated for the first time in Belgium in 1978 (Pensaert and de Bouck 1978; Song and Park 2012); however, the epidemic was not controlled in Europe before 2000. In China, PEDV was first identified in the 1980s, after which it was reported in some Asian countries, e.g., Japan and Korea (Kusanagi et al. 1992; Song and Park 2012; Takahashi et al. 1983). In October 2010, a severe PED outbreak caused by a highly virulent PEDV variant emerged in southern China with high mortality ranging from 70 to $100 \%$; the result was devastating damage to the pig farm industry and tremendous economic losses, and later, the PEDV variant spreads to other countries, e.g., USA, Canada, and Mexico (Chen et al. 2012; Chen et al. 2010; Ge et al. 2013; Jung and Saif 2015; Li et al. 2012; Ojkic et al. 2015;

Sun et al. 2012; Tian et al. 2014; Yang et al. 2014; Yang et al. 2013). Currently, PED remains a critical threat to the global swine industry.

For the early and rapid detection of PEDV, different types of PCR methods have been developed. A real-time reverse transcription recombinase polymerase amplification assay (RT-RPA) based on the nucleocapsid gene of PEDV was reported in 2018; the assay was able to detect 23 copies per reaction and was performed for $20 \mathrm{~min}$ at $40{ }^{\circ} \mathrm{C}$ (Wang et al. 2018). Based on the advantage of increased thermal conductivity of solid gold nanometal particles that could reduce nonspecific amplification and increase specific amplification, Yuan et al. developed a nanoparticle-assisted PCR assay for the detection of PEDV on the basis of the $\mathrm{N}$ gene in 2015, and the assay could detect $2.7 \times 10^{-6} \mathrm{ng} / \mu \mathrm{l}$ of PEDV RNA (Yuan et al. 2015). Ren and Li designed six primers according to the sequence of the $\mathrm{N}$ gene and established a reverse transcription loop-mediated isothermal amplification (RT-LAMP) for the rapid detection of PEDV (within $50 \mathrm{~min}$ ) at $63^{\circ} \mathrm{C}$. The detection limit of the method was $1 \times 10^{-4} \mu \mathrm{g}$ PEDV RNA per reaction (Ren and Li 2011). Wang et al. designed five primers on the basis of the $\mathrm{N}$ gene sequence of PEDV and established a reverse transcription cross-priming amplification-nucleic acid test strip (CPA-NAST) for the detection of PEDV. The method had high specificity for the detection of PEDV and had the same sensitivity as traditional RT-PCR; the detection limit was a $10^{-6}$ dilution of plasmid containing the target gene (Wang et al. 2016). Xing et al. developed an RNA extraction and transcription-free, nanoparticle-based PCR (NBP-PCR) method to specifically detect PEDV, and the sensitivity of 
the method was 400 -fold higher than that of conventional RTPCR. In 153 fecal samples, the positive detection rate of NBPPCR specific was much higher than that of conventional RTPCR (5.88\%) and SYBR Green real-time RT-PCR (Xing et al. 2016). Zhou et al. developed a conventional RT-PCR method, an SYBR Green I real-time RT-PCR, and TaqMan real-time RT-PCR reagents to detect the highly conserved $\mathrm{M}$ gene of PEDV; the detection limit of the TaqMan real-time RT-PCR was $10 \mathrm{copies} / \mu \mathrm{l}$ of the target gene, and the sensitivity of the TaqMan real-time RT-PCR was 100-fold and 10,000-fold higher than that of SYBR Green I real-time RT-PCR and conventional RT-PCR, respectively (Zhou et al. 2017).

In addition, there were variant PEDV strains circulating in the field and the PCR methods for differentiating them had been established. Song et al. analyzed pathogenicity and immunogenicity of PEDV strain designated DR13 in piglets, which was a highly Vero cell-adapted virus and could be employed as a vaccine candidate, and applied a restriction fragment length polymorphism (RFLP) assay to differentiate DR13 from wild-type virus based on the difference of open reading frame (ORF) 3 sequence (Song et al. 2003). In 2008, Lee et al. reported an RT-PCR-based RFLP assay targeting the $\mathrm{N}$ gene of PEDV to distinguish field strains of PEDV in Korea from an attenuated-live vaccine J-vac, which was used in pig population to prevent PEDV (Lee et al. 2008). For differentiation between attenuated-type PEDVs including attenuated DR13, KPED-9, and P-5V that were used as live virus vaccine and wild-type PEDVs including CV777, $\mathrm{Brl} /$ 87, LZC, parent DR13, and field samples, Park et al. established an RT-PCR assay based on the difference of ORF 3 gene sequence of attenuated- and wild-type PEDV, in which 51 nucleotide deletions were found in all live PEDV vaccine (Park et al. 2008). In May 2013, the virulent strain of PEDV was verified in the USA resulting in significant economic losses in the swine industry. And a variant strain (OH851) of PEDV emerged in the USA in December 2013, which differs from the virulent strains of PEDV in the nucleotides of the 5 'end of spike gene. To differentiate these two genotypes of PEDV circulating in the USA, Wang et al. reported a duplex probe-based real-time RT-PCR targeting the difference of spike gene among virulent and variant strains (Wang et al. 2014b). Sequence analysis of PEDV genome indicated that PEDV attenuated vaccine strains (e.g., the CV777 and ZJ08 in China, the P-5V in Japan, and KPED-9 and DR13 in South Korea in Asia) have 49 base pair deletion in the open reading frame 3 (ORF3); for differentiation of these cell-adapted vaccine strains from field strains, Zhu et al. developed a nanoparticle-assisted RT-PCR assay targeting the ORF3 (Zhu et al. 2016b). Because three major PEDV types have been identified in the USA after 2013 including the original US PEDV strains, the spike gene insertion-deletion PEDV strains, and the PC177 strain that possess a 197 amino acid-deletion in the S1region of spike protein, Liu and Wang developed a reverse transcription-PCR method to differentiate these variants on the basis of differences in the S1 gene (Liu and Wang 2016). Since 2010, PEDV variants with base deletions and insertions in the $\mathrm{S}$ gene emerged in China and caused significant losses in piglets; Zhao et al. developed a TaqMan probe-based real-time PCR method for the detection of different PEDV variants and classical PEDV strains based on the sequence difference of the PEDV $S$ gene, and the detection limit of the method was $5 \times$ $10^{2}$ target gene copies (Zhao et al. 2014). Su et al. established a duplex TaqMan probe real-time RT-qPCR method for detecting and differentiating classical and variant PEDVs targeting the difference in the $\mathrm{S}$ gene; the detection limit of the method was $4.8 \times 10^{2}$ genome copies/reaction for both the classical and variant PEDV. The results of clinical sample detection showed that the assay was more sensitive than conventional PCR, and variant PEDV was prevalent in China ( $\mathrm{Su}$ et al. 2018). Due to the wide use of a live attenuated PEDV vaccine, classical and wild variant strains circulating in pig farms are common; therefore, He et al. established a multiplex RT-PCR to differentiate these strains based on the difference in $\mathrm{S}$ gene sequences, and the detection limit of the method was $1 \times 10^{1.7} \mathrm{TCID}_{50} / 100 \mu \mathrm{l}$ for PEDV (He et al. 2019). Due to variant PEDV strains that emerged in China since 2010 and attenuated PEDV vaccines (e.g., CV777 strain) being widely used in China, Liu et al. reported a TaqMan probe-based realtime PCR to differentiate these virulent strains and attenuated vaccine strains based on the ORF3 deletion region to detect virulent PEDV strains in vaccinated pig population (Liu et al. 2019b).

\section{TGEV detection by PCR-based methods}

Transmissible gastroenteritis (TGE) caused by TGEV is an acute enteric diarrhea disease in pigs (Garwes 1988). TGEV was isolated for the first time in 1946, and then outbreaks of the virus occurred in many countries in America, Asia, and Europe (Doyle and Hutchings 1946; Kim et al. 2000; Stevenson et al. 2013). TGEV causes severe enteritis in piglets before weaning, and the clinical signs include diarrhea, vomiting, dehydration, and high mortality, resulting in significant economic losses (Ding et al. 2017; Penzes et al. 2001; Saif 1999).

For the early and rapid detection of TGEV, different types of PCR-based methods have been established. Chen et al. designed six specific primers targeting the nucleocapsid gene of TGEV and developed an RT-LAMP assay for the detection of TGEV, which involved incubation at $60{ }^{\circ} \mathrm{C}$ for $1 \mathrm{~h}$. The sensitivity of RT-LAMP was comparable to that of nested PCR described by Rodríguez et al. in 2008, and it was 10 times more sensitive than the PCR reported by Paton et al. in 1997, which could detect 10 pg of RNA per reaction (Chen et al. 
2010; Paton et al. 1997; Rodríguez et al. 2008). RT-LAMP for the detection of the TGEV targeting the $\mathrm{N}$ gene sequence by incubation at $60{ }^{\circ} \mathrm{C}$ for 30 min was reported by Li et al., and the sensitivity of RT-LAMP was much higher than that of a gel-based RT-PCR kit purchased from HaiGene Company, China (Li et al. 2012). Vemulapalli et al. described a TaqMan probe-based real-time RT-PCR that specifically amplified conserved $\mathrm{S}$ gene sequences. The detection limit of the method was $1 \mathrm{TCID}_{50} / \mathrm{ml}$ of TGEV RNA. The sensitivity of the assay was higher than that of the nested RT-PCR assay reported by Kim et al. (Kim et al. 2000; Vemulapalli et al. 2009). Wang et al. developed a rapid detection of TGEV using real-time reverse transcription recombinase polymerase amplification (RT-RPA) based on the spike gene, and the method could detect 100 copies of TGEV RNA after $20 \mathrm{~min}$ at $40{ }^{\circ} \mathrm{C}$ conditions (Wang et al. 2018). A real-time RT-PCR assay described by Vemulapalli et al. was compared with the RTRPA method in the analysis of 76 clinical samples, and the two methods generated the same results (Vemulapalli et al. 2009; Wang et al. 2018). In the mid-1980s, PRCoV, which has a deletion of nucleotides of the $\mathrm{S}$ gene that is present in TGEV (Laude et al. 1993), was reported in Europe, North America, and Asia (Pensaert et al. 1986; Wesley et al. 1990). Paton et al. developed an RT-PCR assay to differentiate TGEV and PRCV based on the difference in the $\mathrm{S}$ gene of the two viruses (Paton et al. 1997).

\section{PDCoV detection by PCR-based methods}

$\mathrm{PDCoV}$ is a novel swine enteric diarrhea virus that causes severe diarrhea, vomiting, and dehydration in piglets (Janetanakit et al. 2016; Song et al. 2015). PDCoV was first discovered in samples from the healthy pig that were collected in 2009 in Hong Kong when a molecular surveillance study was performed (Woo et al. 2012). In February 2014, the virus was detected in piglets with severe diarrhea in the USA (Marthaler et al. 2014; Wang et al. 2014a). Subsequently, PDCoV was reported in South Korea, mainland China, and Thailand (Chen et al. 2015a; Janetanakit et al. 2016; Lee and Lee 2014; Song et al. 2015).

To detect the virus with precision, PCR-based methods have been created. In 2014, pigs on 5 farms in Ohio, USA, had clinical diarrheal disease. Wang et al. developed a onestep RT-PCR targeting membrane and nucleocapsid gene of delta-CoV and determined the causative agent as porcine delta-CoVs, but they did not evaluate the detection limit of the assay (Wang et al. 2014a). In 2015, Song et al. established a nested RT-PCR method on the basis of the nucleocapsid gene sequence of the PDCoV HKU15 strain to identify the causative agent causing acute diarrhea in a pig farm in Jiangxi, China, and the sensitivity of the assay was also not determined (Song et al. 2015). To analyze the characteristics of porcine
delta-CoVs in the USA, Ma et al. established a real-time RTPCR method for specific detection of the $\mathrm{N}$ gene, but the sensitivity of the assay was also not determined (Ma et al. 2015). For the analysis of pathogenicity and pathogenesis of a porcine delta-CoV cell culture isolate, Chen et al. developed an M gene-based real-time PCR method for detecting viral titers in different organs, but the sensitivity of the assay was not described in the publication (Chen et al. 2015b). Marthaler et al. developed a one-step probe-based real-time RT-PCR method targeting the $\mathrm{M}$ gene sequence of $\mathrm{PDCoV}$, which was applied by the University of Minnesota Veterinary Diagnostic Laboratory. The detection limit of the assay was 2 viral RNA copies per reaction, but the specificity of the assay was not evaluated (Marthaler et al. 2014). The commercial reverse transcription-insulated isothermal PCR (RTiiPCR) POCKITTM methods (POCKIT ${ }^{\text {TM }}$ PEDV Reagent Set and POCKITTM PDCoV Reagent Set, GeneReach USA, Lexington, MA, USA) was used to analyze PEDV and PDCoV coinfection that occurred in diarrhea disease; Zhang et al. described two singleplex RT-iiPCR tests and a duplex real-time RT-PCR test for the detection of PEDV and PDCoV that were based on targeting the conserved $\mathrm{M}$ gene sequence. The detection limits of singleplex RT-iiPCR were 21 RNA copies per reaction for PEDV and 9 RNA copies per reaction for PDCoV, and those of the duplex RT-iiPCR were 7 RNA copies and 14 RNA copies per reaction for PEDV and PDCoV, respectively (Zhang et al. 2016).

\section{SADS-CoV detection by PCR-based methods}

SADS-CoV, also designated SeACoV or PEAV, is a novel porcine enteric diarrhea virus that can cause severe and acute diarrhea and rapid weight loss in piglets (Pan et al. 2017; Zhou et al. 2018; Zhou et al. 2017). SADS-CoV was identified for the first time in southern China in late 2017, and it caused more than 24,000 piglet deaths, resulting in significant economic losses (Gong et al. 2017). The clinical signs of infection with SADS-CoV are similar to those of other known swine enteric CoVs: TGEV, PEDV, and PDCoV (Dong et al. 2015; Sun et al. 2016).

For specific detection of SADS-CoV, Zhou et al. established an SYBR premix Ex TaqII-based real-time PCR on the basis of the RNA-dependent RNA polymerase (RdRp) gene for the detection of SADS-CoV; the sensitivity of which was not evaluated (Zhou et al. 2017). Zhou et al. developed a TaqMan-based real-time PCR assay for SADS-CoV detection based on the conserved sequence within the $\mathrm{N}$ gene; the detection limit of the assay was $3.0 \times 10^{1} \mathrm{copies} / \mu \mathrm{l}$, and the sensitivity of the method was 10 -fold higher than that of conventional PCR, which also targeted the $\mathrm{N}$ gene (Zhou et al. 2018). 
Multiplex PCR-based methods for differential detection of pathogenic swine enteric CoVs

Because the clinical signs caused by the four enteric CoVs in piglets are similar to each other, it is very difficult or timeconsuming to make a clear diagnosis of mixed infection in pigs using a single PCR method. Therefore, it is critical to developing a multiplex polymerase chain reaction (mPCR) in which two or more loci can be simultaneously detected in the same reaction (Chamberlain et al. 1988). TGEV and PEDV are traditional swine enteric diarrheal viruses, so several mPCR methods that can differentially detect the two viruses have been previously established. In 2001, Kim et al. reported a duplex RT-PCR assay to detect TGEV and PEDV in one PCR tube targeting the $\mathrm{S}$ gene of the two viruses, and the detection limit of the assay was $2 \mathrm{TCID}_{50} / 200 \mu \mathrm{l}$ (Kim et al. 2001). In 2007, Kim et al. established a multiplex realtime RT-PCR method based on the nucleocapsid (N) gene for the simultaneous detection and quantification of TGEV and PEDV, and the detection limits of this method were 90 copies and 70 copies for TEGV and PEDV, respectively (Kim et al. 2007). Zhu et al. designed two pairs of primers on the basis of the $\mathrm{N}$ gene sequences of TGEV and PEDV and established a nanoparticle-associated PCR assay; the sensitivity of the assay was 10-fold higher than that of conventional PCR (Zhu et al. 2017)

Apart from the four enteric CoVs, several enteric diarrheal viruses have been discovered, including porcine sapovirus $(\mathrm{PSaV})$, porcine norovirus (PNoV), porcine Teschen virus (PTV), porcine kobuvirus (PKV), Seneca Valley virus (SVV), porcine rotavirus ( $\mathrm{PRV}$ ), porcine reovirus (ReoV), porcine bocavirus (PBoV), and porcine astrovirus (PAstV). Therefore, some mPCR methods have been created to detect swine enteric diarrheal viruses, but they are not limited to enteric CoVs (Ding et al. 2019). Ben Salem et al. developed a nested RT-PCR method for the detection of PEDV, TGEV, and PRV based on the sequence of the TGEV Purdue strain (accession no. NC_002306), the PEDV strain CV777 (accession no. NC_003436), and the NSP5 gene of the PRVA OSU strain (accession no. X15519), respectively. The detection limits of multiplex nested RT-PCR for TGEV and PEDV were $10^{2} \mathrm{TCID}_{50} / \mathrm{ml}$ and $27.2 \mu \mathrm{g} / \mu \mathrm{l}$ of RNA, respectively (Ben Salem et al. 2010). In 2013, Zhao et al. developed a multiplex RT-PCR assay to identify PEDV, TGEV, PRV-A, and porcine circovirus 2 (PCV2) in one reaction, and the sensitivity of the assay for the detection of TGEV and PEDV was 10-fold lower than that of a single RT-PCR method (Zhao et al. 2013). Zhao et al. established a multiplex RT-PCR assay for rapid and differential diagnosis of PEDV, TGEV, PRV-A, and PCV2 targeting the $\mathrm{S}$ gene, segment 6 region, and ORF2 sequence, and the detection limits of the assay for TGEV and PEDV were $1.74 \times 10^{4}$ and $2.1 \times 10^{3}$ copies, respectively (Zhao et al. 2013). Liu et al. developed a multiplex PCR assay to detect five diarrhea-related pig viruses: PEDV (nucleoprotein), TGEV (spike glycoprotein), PRV-A, porcine group C rotaviruses (PRV-C), and PCV2. The detection limits of the assay for PEDV and TGEV were 5 copies per reaction (Liu et al. 2019a). Wen et al. developed a multiplex real-time PCR method based on EvaGreen fluorescent dye to simultaneously detect and distinguish PEDV-nucleoprotein (N), TGEV-spike glycoprotein (S), PRV-A, PRV-C, and PCV2, and the limits of detection ranged from 5 to 50 copies/ $\mu$ (Wen et al. 2019). There was no multiplex PCR method exclusively for differential detection of the four enteric CoVs until Huang et al. developed a TaqMan-probe-based real-time RT-PCR method in 2019 targeting the $\mathrm{M}$ gene of PEDV, the $\mathrm{N}$ gene of TGEV, the $\mathrm{M}$ gene of PDCoV, and the $\mathrm{N}$ gene of SADS-CoV. Their multiplex real-time RT-qPCR assay could detect 10-100 copies of each target gene per pathogen (Huang et al. 2019).

\section{Conclusion and perspectives}

As mentioned above, nested RT-PCR, RT-RPA, nanoparticleassisted PCR, RT-LAMP, CPA-NAST, SYBR green-based real-time PCR, EvaGreen-based real-time PCR, and TaqMan probe-based real-time PCR represent single or multiplex PCR methods that have been developed to detect one, two, or four enteric pathogenic CoVs. In the field, the causative agents of swine enteric diarrhea are mixed; single RT-PCR methods are not suitable for rapid and efficient detection of CoVs even though they have higher sensitivity than multiplex RT-PCR. In addition, the PCR fragments of some single RT-PCR methods have to be subjected to agarose gel analysis to determine results, which is time-consuming. In particular, nested RT-PCR requires two PCR steps, resulting in an increased likelihood of contamination, so this method has not been widely used for pathogen detection.

For rapid and efficient detection of pathogenic swine enteric CoVs, multiplex PCR methods, including conventional multiplex RT-PCR and multiplex real-time RT-PCR, are ideal options. Although conventional multiplex RT-PCR can simultaneously differentially detect several different pathogens in one reaction, the method also possesses the disadvantages of single RT-PCR, e.g., risk of product contamination, and the inability to monitor developments in real time. The sensitivity of RT-PCR is 10-100 times lower than that of real-time RTPCR, and the viral loads cannot be measured (Keyaerts et al. 2006). Recently, real-time TaqMan probe-based RT-PCR methods have become increasingly used to detect targets because they own many advantageous characteristics: the ability to perform differential detection, high specificity, high sensitivity, high-throughput ability, high repeatability, quantification ability, and the ability to assess results in real time (Slavov et al. 2016; Teng et al. 2015; Zhu et al. 2016a). Therefore, Huang et al. in our lab developed a TaqMan-probe-based real- 
time RT-PCR for the differential detection of PEDV, TGEV, PDCoV, and PEAV (Huang et al. 2019).

Although real-time TaqMan probe-based RT-PCR possesses many merits and can be used to rapidly and efficiently detect pathogenic swine enteric CoVs, the method requires a high-precision and sophisticated instrument, practical technicians, and a good laboratory; therefore, it cannot be used for detection in under-equipped laboratories or on-site. Rapid, accurate, and more practical detection methods are of great significance for the surveillance, prevention, and control of enteric diseases in pigs, so novel assays are still deserved further development. For instance, test strip detection methods, which can be used by under-equipped laboratories or on-site and can be easily operated to quickly generate results, are urgently needed.

As mentioned earlier, apart from the four enteric $\mathrm{CoVs}$, many other pathogens causing diarrhea in pigs have been identified. And the causative agents of swine enteric diarrhea are mixed in the field. To rapidly determine whether the pathogens are enteric CoVs, pan-CoV PCR is the best option to initially detect from clinical samples and followed by specific primers targeting individual swine enteric coronavirus for further identification when the result from pan-CoV PCR is positive. However, when the pan-CoV PCR results are negative, specific primers targeting other enteric diarrheal viruses are required to determine the causative agents.

Authors' contributions YF and GL conceived the review. FY and BL collected all references and wrote the manuscript draft. GL edited the manuscript.

Funding information This study was supported by the National Key R\&D Program of China (2016YFD0500103), the National Natural Science Foundation of China $(31972689,31572498)$, and the Elite Youth Program of CAAS, and partly by China Central Public-interest Scientific Institution Basal Research Fund (1610312020020).

\section{Compliance with ethical standards}

Conflict of interest The authors declare that they have no competing interests.

Ethical statement No ethical approval was required as this is a review article with no original research data.

\section{References}

Ben Salem AN, Chupin Sergei A, Bjadovskaya Olga P, Andreeva Olga G, Mahjoub A, Prokhvatilova Larissa B (2010) Multiplex nested RT-PCR for the detection of porcine enteric viruses. J Virol Methods 165(2):283-293. https://doi.org/10.1016/j.jviromet.2010. 02.010

Bolles M, Donaldson E, Baric R (2011) SARS-CoV and emergent coronaviruses: viral determinants of interspecies transmission. Curr Opin Virol 1(6):624-634. https://doi.org/10.1016/j.coviro. 2011.10.012
Carman S, Josephson G, McEwen B, Maxie G, Antochi M, Eernisse K, Nayar G, Halbur P, Erickson G, Nilsson E (2002) Field validation of a commercial blocking ELISA to differentiate antibody to transmissible gastroenteritis virus (TGEV) and porcine respiratory coronavirus and to identify TGEV-infected swine herds. J Vet Diagn Investig 14(2):97-105. https://doi.org/10.1177/104063870201400202

Chamberlain JS, Gibbs RA, Ranier JE, Nguyen PN, Caskey CT (1988) Deletion screening of the Duchenne muscular dystrophy locus via multiplex DNA amplification. Nucleic Acids Res 16(23):1114111156. https://doi.org/10.1093/nar/16.23.11141

Chan JF, To KK, Tse H, Jin DY, Yuen KY (2013) Interspecies transmission and emergence of novel viruses: lessons from bats and birds. Trends Microbiol 21(10):544-555. https://doi.org/10.1016/j.tim. 2013.05.005

Chen F, Pan Y, Zhang X, Tian X, Wang D, Zhou Q, Song Y, Bi Y (2012) Complete genome sequence of a variant porcine epidemic diarrhea virus strain isolated in China. J Virol 86(22):12448. https://doi.org/ 10.1128/jvi.02228-12

Chen F, Zhu Y, Wu M, Ku X, Yao L, He Q (2015a) Full-length genome characterization of Chinese porcine deltacoronavirus strain $\mathrm{CH} /$ SXD1/2015. Genome Announc 3(5). https://doi.org/10.1128/ genomeA.01284-15

Chen J, Wang C, Shi H, Qiu H, Liu S, Chen X, Zhang Z, Feng L (2010) Molecular epidemiology of porcine epidemic diarrhea virus in China. Arch Virol 155(9):1471-1476. https://doi.org/10.1007/ s00705-010-0720-2

Chen Q, Gauger P, Stafne M, Thomas J, Arruda P, Burrough E, Madson D, Brodie J, Magstadt D, Derscheid R, Welch M, Zhang J (2015b) Pathogenicity and pathogenesis of a United States porcine deltacoronavirus cell culture isolate in 5-day-old neonatal piglets. Virology 482:51-59. https://doi.org/10.1016/j.virol.2015.03.024

Collins PJ, Martella V, O'Shea H (2008) Detection and characterization of group $\mathrm{C}$ rotaviruses in asymptomatic piglets in Ireland. J Clin Microbiol 46(9):2973-2979. https://doi.org/10.1128/jcm.00809-08

Ding G, Fu Y, Li B, Chen J, Wang J, Yin B, Sha W, Liu G (2019) Development of a multiplex RT-PCR for the detection of major diarrhoeal viruses in pig herds in China. Transbound Emerg Dis 67:678-685. https://doi.org/10.1111/tbed.13385

Ding Z, An K, Xie L, Wu W, Zhang R, Wang D, Fang Y, Chen H, Xiao S, Fang L (2017) Transmissible gastroenteritis virus infection induces NF-kappaB activation through RLR-mediated signaling. Virology 507:170-178. https://doi.org/10.1016/j.virol.2017.04.024

Dong N, Fang L, Zeng S, Sun Q, Chen H, Xiao S (2015) Porcine deltacoronavirus in mainland China. Emerg Infect Dis 21(12): 2254-2255. https://doi.org/10.3201/eid2112.150283

Doyle LP, Hutchings LM (1946) A transmissible gastroenteritis in pigs. J Am Vet Med Assoc 108:257-259

Dulac GC, Ruckerbauer GM, Boulanger P (1977) Transmissible gastroenteritis: demonstration of the virus from field specimens by means of cell culture and pig inoculation. Can J Comp Med 41(4):357-363

Escutenaire S, Mohamed N, Isaksson M, Thoren P, Klingeborn B, Belak S, Berg M, Blomberg J (2007) SYBR Green real-time reverse transcription-polymerase chain reaction assay for the generic detection of coronaviruses. Arch Virol 152(1):41-58. https://doi.org/10. 1007/s00705-006-0840-x

Garwes DJ (1988) Transmissible gastroenteritis. Vet Rec 122(19):462_ 463. https://doi.org/10.1136/vr.122.19.462

Ge FF, Yang DQ, Ju HB, Wang J, Liu J, Liu PH, Zhou JP (2013) Epidemiological survey of porcine epidemic diarrhea virus in swine farms in Shanghai, China. Arch Virol 158(11):2227-2231. https:// doi.org/10.1007/s00705-013-1722-7

Gong L, Li J, Zhou Q, Xu Z, Chen L, Zhang Y, Xue C, Wen Z, Cao Y (2017) A new bat-HKU2-like coronavirus in swine, China, 2017. Emerg Infect Dis 23(9):1607-1609. https://doi.org/10.3201/ eid2309.170915 
Have P, Moving V, Svansson V, Uttenthal A, Bloch B (1992) Coronavirus infection in mink (Mustela vison). Serological evidence of infection with a coronavirus related to transmissible gastroenteritis virus and porcine epidemic diarrhea virus. Vet Microbiol 31(1):1-10. https://doi.org/10.1016/0378-1135(92)90135-g

He D, Chen F, Ku X, Yu X, Li B, Li Z, Sun Q, Fan S, He Q (2019) Establishment and application of a multiplex RT-PCR to differentiate wild-type and vaccine strains of porcine epidemic diarrhea virus. J Virol Methods 272:113684. https://doi.org/10.1016/j.jviromet. 2019.113684

Hsu TH, Liu HP, Chin CY, Wang C, Zhu WZ, Wu BL, Chang YC (2018) Detection, sequence analysis, and antibody prevalence of porcine deltacoronavirus in Taiwan. Arch Virol 163(11):3113-3117. https://doi.org/10.1007/s00705-018-3964-x

Hu H, Jung K, Wang Q, Saif LJ, Vlasova AN (2018) Development of a one-step RT-PCR assay for detection of pancoronaviruses (alpha-, beta-, gamma-, and delta-coronaviruses) using newly designed degenerate primers for porcine and avian 'fecal samples. J Virol Methods 256:116-122. https://doi.org/10.1016/j.jviromet.2018.02. 021

Huang X, Chen J, Yao G, Guo Q, Wang J, Liu G (2019) A TaqManprobe-based multiplex real-time RT-qPCR for simultaneous detection of porcine enteric coronaviruses. Appl Microbiol Biotechnol 103(12):4943-4952. https://doi.org/10.1007/s00253-019-09835-7

Janetanakit T, Lumyai M, Bunpapong N, Boonyapisitsopa S, Chaiyawong S, Nonthabenjawan N, Kesdaengsakonwut S, Amonsin A (2016) Porcine deltacoronavirus, Thailand, 2015. Emerg Infect Dis 22(4):757-759. https://doi.org/10.3201/eid2204. 151852

Jung K, Hu H, Saif LJ (2016) Porcine deltacoronavirus infection: etiology, cell culture for virus isolation and propagation, molecular epidemiology and pathogenesis. Virus Res 226:50-59. https://doi.org/ 10.1016/j.virusres.2016.04.009

Jung K, Saif LJ (2015) Porcine epidemic diarrhea virus infection: etiology, epidemiology, pathogenesis and immunoprophylaxis. Vet J 204(2):134-143. https://doi.org/10.1016/j.tvj1.2015.02.017

Keyaerts E, Vijgen L, Maes P, Duson G, Neyts J, Van Ranst M (2006) Viral load quantitation of SARS-coronavirus RNA using a one-step real-time RT-PCR. Int J Infect Dis 10(1):32-37. https://doi.org/10. 1016/j.ijid.2005.02.003

Kim L, Chang KO, Sestak K, Parwani A, Saif LJ (2000) Development of a reverse transcription-nested polymerase chain reaction assay for differential diagnosis of transmissible gastroenteritis virus and porcine respiratory coronavirus from feces and nasal swabs of infected pigs. J Vet Diagn Investig 12(4):385-388. https://doi.org/10.1177/ 104063870001200418

Kim SH, Kim IJ, Pyo HM, Tark DS, Song JY, Hyun BH (2007) Multiplex real-time RT-PCR for the simultaneous detection and quantification of transmissible gastroenteritis virus and porcine epidemic diarrhea virus. J Virol Methods 146(1-2):172-177. https:// doi.org/10.1016/j.jviromet.2007.06.021

Kim SY, Song DS, Park BK (2001) Differential detection of transmissible gastroenteritis virus and porcine epidemic diarrhea virus by duplex RT-PCR. J Vet Diagn Investig 13(6):516-520. https://doi.org/ $10.1177 / 104063870101300611$

Kusanagi K, Kuwahara H, Katoh T, Nunoya T, Ishikawa Y, Samejima T, Tajima M (1992) Isolation and serial propagation of porcine epidemic diarrhea virus in cell cultures and partial characterization of the isolate. J Vet Med Sci 54(2):313-318. https://doi.org/10.1292/ jvms. 54.313

Laude H, Van Reeth K, Pensaert M (1993) Porcine respiratory coronavirus: molecular features and virus-host interactions. Vet Res 24(2): $125-150$

Lazov CM, Chriel M, Baagoe HJ, Fjederholt E, Deng Y, Kooi EA, Belsham GJ, Botner A, Rasmussen TB (2018) Detection and characterization of distinct alphacoronaviruses in five different bat species in Denmark. Viruses 10(9). https://doi.org/10.3390/ v10090486

Lee C, Park CK, Lyoo YS, Lee du S (2008) Genetic differentiation of the nucleocapsid protein of Korean isolates of porcine epidemic diarrhoea virus by RT-PCR based restriction fragment length polymorphism analysis. Vet J 178(1):138-140 doi:https://doi.org/10.1016/j. tvj1.2007.07.007

Lee S, Lee C (2014) Complete genome characterization of Korean porcine deltacoronavirus strain KOR/KNU14-04/2014. Genome Announc 2(6). https://doi.org/10.1128/genomeA.01191-14

Li G, Chen Q, Harmon KM, Yoon KJ, Schwartz KJ, Hoogland MJ, Gauger PC, Main RG, Zhang J (2014) Full-length genome sequence of porcine deltacoronavirus strain USA/IA/2014/8734. Genome Announc 2(2). https://doi.org/10.1128/genomeA.00278-14

Li W, Li H, Liu Y, Pan Y, Deng F, Song Y, Tang X, He Q (2012) New variants of porcine epidemic diarrhea virus, China, 2011. Emerg Infect Dis 18(8):1350-1353. https://doi.org/10.3201/eid1808. 120002

Liu G, Jiang Y, Opriessnig T, Gu K, Zhang H, Yang Z (2019a) Detection and differentiation of five diarrhea related pig viruses utilizing a multiplex PCR assay. J Virol Methods 263:32-37. https://doi.org/ 10.1016/j.jviromet.2018.10.009

Liu J, Li LM, Han JQ, Sun TR, Zhao X, Xu RT, Song QY (2019b) A TaqMan probe-based real-time PCR to differentiate porcine epidemic diarrhea virus virulent strains from attenuated vaccine strains. Mol Cell Probes 45:37-42. https://doi.org/10.1016/j.mcp.2019.04.003

Liu X, Wang Q (2016) Reverse transcription-PCR assays for the differentiation of various US porcine epidemic diarrhea virus strains. $\mathrm{J}$ Virol Methods 234:137-141. https://doi.org/10.1016/j.jviromet. 2016.04.018

Ma Y, Zhang Y, Liang X, Lou F, Oglesbee M, Krakowka S, Li J (2015) Origin, evolution, and virulence of porcine deltacoronaviruses in the United States. mBio 6(2):e00064. https://doi.org/10.1128/mBio. 00064-15

Marthaler D, Raymond L, Jiang Y, Collins J, Rossow K, Rovira A (2014) Rapid detection, complete genome sequencing, and phylogenetic analysis of porcine deltacoronavirus. Emerg Infect Dis 20(8): 1347-1350. https://doi.org/10.3201/eid2008.140526

Moes E, Vijgen L, Keyaerts E, Zlateva K, Li S, Maes P, Pyrc K, Berkhout B, van der Hoek L, Van Ranst M (2005) A novel pancoronavirus RT-PCR assay: frequent detection of human coronavirus NL63 in children hospitalized with respiratory tract infections in Belgium. BMC Infect Dis 5:6. https://doi.org/10.1186/1471-2334-5-6

Ojkic D, Hazlett M, Fairles J, Marom A, Slavic D, Maxie G, Alexandersen S, Pasick J, Alsop J, Burlatschenko S (2015) The first case of porcine epidemic diarrhea in Canada. Can Vet J 56(2):149152

Pan Y, Tian X, Qin P, Wang B, Zhao P, Yang YL, Wang L, Wang D, Song Y, Zhang X, Huang YW (2017) Discovery of a novel swine enteric alphacoronavirus ( $\mathrm{SeACoV})$ in southern China. Vet Microbiol 211:15-21. https://doi.org/10.1016/j.vetmic.2017.09.020

Park SJ, Moon HJ, Luo Y, Kim HK, Kim EM, Yang JS, Song DS, Kang BK, Lee CS, Park BK (2008) Cloning and further sequence analysis of the ORF3 gene of wild- and attenuated-type porcine epidemic diarrhea viruses. Virus Genes 36(1):95-104. https://doi.org/10. 1007/s11262-007-0164-2

Paton D, Ibata G, Sands J, McGoldrick A (1997) Detection of transmissible gastroenteritis virus by RT-PCR and differentiation from porcine respiratory coronavirus. J Virol Methods 66(2):303-309. https://doi.org/10.1016/s0166-0934(97)00055-4

Pensaert M, Callebaut P, Vergote J (1986) Isolation of a porcine respiratory, non-enteric coronavirus related to transmissible gastroenteritis. Vet Q 8(3):257-261. https://doi.org/10.1080/01652176.1986. 9694050 
Pensaert MB, de Bouck P (1978) A new coronavirus-like particle associated with diarrhea in swine. Arch Virol 58(3):243-247. https://doi. org/10.1007/bf01317606

Penzes Z, Gonzalez JM, Calvo E, Izeta A, Smerdou C, Mendez A, Sanchez CM, Sola I, Almazan F, Enjuanes L (2001) Complete genome sequence of transmissible gastroenteritis coronavirus PUR46MAD clone and evolution of the purdue virus cluster. Virus Genes 23(1):105-118. https://doi.org/10.1023/a:1011147832586

Ren X, Li P (2011) Development of reverse transcription loop-mediated isothermal amplification for rapid detection of porcine epidemic diarrhea virus. Virus Genes 42(2):229-235. https://doi.org/10. 1007/s11262-011-0570-3

Rodríguez E, Betancourt A, Barrera M, Lee C, Yy D (2008) Rapid detection of swine transmissible gastroenteritis virus by nested polymerase chain reaction. Rev Salud Anim 30(2):4

Saif LJ (1999) Comparative pathogenesis of enteric viral infections of swine. Adv Exp Med Biol 473:47-59. https://doi.org/10.1007/9781-4615-4143-1 4

Shibata I, Tsuda T, Mori M, Ono M, Sueyoshi M, Uruno K (2000) Isolation of porcine epidemic diarrhea virus in porcine cell cultures and experimental infection of pigs of different ages. Vet Microbiol 72(3-4):173-182. https://doi.org/10.1016/s0378-1135(99)00199-6

Slavov SN, Otaguiri KK, de Figueiredo GG, Yamamoto AY, MussiPinhata MM, Kashima S, Covas DT (2016) Development and optimization of a sensitive TaqMan(R) real-time PCR with synthetic homologous extrinsic control for quantitation of Human cytomegalovirus viral load. J Med Virol 88(9):1604-1612. https://doi.org/10. 1002/jmv.24499

Song D, Park B (2012) Porcine epidemic diarrhoea virus: a comprehensive review of molecular epidemiology, diagnosis, and vaccines. Virus Genes 44(2):167-175. https://doi.org/10.1007/s11262-0120713-1

Song D, Zhou X, Peng Q, Chen Y, Zhang F, Huang T, Zhang T, Li A, Huang D, Wu Q, He H, Tang Y (2015) Newly emerged porcine deltacoronavirus associated with diarrhoea in swine in China: identification, prevalence and full-length genome sequence analysis. Transbound Emerg Dis 62(6):575-580. https://doi.org/10.1111/ tbed.12399

Song DS, Yang JS, Oh JS, Han JH, Park BK (2003) Differentiation of a Vero cell adapted porcine epidemic diarrhea virus from Korean field strains by restriction fragment length polymorphism analysis of ORF 3. Vaccine 21(17-18):1833-1842. https://doi.org/10.1016/ s0264-410x(03)00027-6

Stevenson GW, Hoang H, Schwartz KJ, Burrough ER, Sun D, Madson D, Cooper VL, Pillatzki A, Gauger P, Schmitt BJ, Koster LG, Killian ML, Yoon KJ (2013) Emergence of porcine epidemic diarrhea virus in the United States: clinical signs, lesions, and viral genomic sequences. J Vet Diagn Investig 25(5):649-654. https:// doi.org/10.1177/1040638713501675

Su Y, Liu Y, Chen Y, Xing G, Hao H, Wei Q, Liang Y, Xie W, Li D, Huang H, Deng R, Zhang G (2018) A novel duplex TaqMan probebased real-time RT-qPCR for detecting and differentiating classical and variant porcine epidemic diarrhea viruses. Mol Cell Probes 37: 6-11. https://doi.org/10.1016/j.mcp.2017.10.003

Sueyoshi M, Tsuda T, Yamazaki K, Yoshida K, Nakazawa M, Sato K, Minami T, Iwashita K, Watanabe M, Suzuki Y, Mori M (1995) An immunohistochemical investigation of porcine epidemic diarrhoea. J Comp Pathol 113(1):59-67. https://doi.org/10.1016/s00219975(05)80069-6

Sun D, Wang X, Wei S, Chen J, Feng L (2016) Epidemiology and vaccine of porcine epidemic diarrhea virus in China: a mini-review. J Vet Med Sci 78(3):355-363. https://doi.org/10.1292/jvms.15-0446

Sun RQ, Cai RJ, Chen YQ, Liang PS, Chen DK, Song CX (2012) Outbreak of porcine epidemic diarrhea in suckling piglets, China. Emerg Infect Dis 18(1):161-163. https://doi.org/10.3201/eid1801. 111259
Takahashi K, Okada K, Ohshima K (1983) An outbreak of swine diarrhea of a new-type associated with coronavirus-like particles in Japan. Nihon Juigaku Zasshi 45(6):829-832. https://doi.org/10.1292/ jvms 1939.45.829

Teng Q, Shen W, Yan D, Yan L, Li X, Li G, Yang J, Li Z (2015) Development of a TaqMan MGB RT-PCR for the rapid detection of H3 subtype avian influenza virus circulating in China. J Virol Methods 217:64-69. https://doi.org/10.1016/j.jviromet.2015.02. 025

Tian PF, Jin YL, Xing G, Qv LL, Huang YW, Zhou JY (2014) Evidence of recombinant strains of porcine epidemic diarrhea virus, United States, 2013. Emerg Infect Dis 20(10):1735-1738. https://doi.org/ 10.3201/eid2010.140338

van Nieuwstadt AP, Cornelissen JB, Vreeswijk J (1988) Solid phase immune electron microscopy for diagnosis of transmissible gastroenteritis in pigs. Res Vet Sci 44(3):286-294

Vemulapalli R, Gulani J, Santrich C (2009) A real-time TaqMan RT-PCR assay with an internal amplification control for rapid detection of transmissible gastroenteritis virus in swine fecal samples. J Virol Methods 162(1-2):231-235. https://doi.org/10.1016/j.jviromet. 2009.08.016

Vijgen L, Moes E, Keyaerts E, Li S, Van Ranst M (2008) A pancoronavirus RT-PCR assay for detection of all known coronaviruses. Methods Mol Biol 454:3-12. https://doi.org/10. 1007/978-1-59745-181-9 1

Wang FX, Yuan DY, Jin YN, Hu L, Sun ZY, He Q, Zhao SH, Zhan SB, Wen YJ (2016) Reverse transcription cross-priming amplificationnucleic acid test strip for rapid detection of porcine epidemic diarrhea virus. Sci Rep 6:24702. https://doi.org/10.1038/srep24702

Wang J, Wang J, Zhang R, Liu L, Shi R, Han Q, Yuan W (2018) Rapid detection of transmissible gastroenteritis virus in swine small intestine samples using real-time reverse transcription recombinase polymerase amplification. J Virol Methods 256:85-88. https://doi.org/ 10.1016/j.jviromet.2018.03.005

Wang L, Byrum B, Zhang Y (2014a) Detection and genetic characterization of deltacoronavirus in pigs, Ohio, USA, 2014. Emerg Infect Dis 20(7):1227-1230. https://doi.org/10.3201/eid2007.140296

Wang L, Zhang Y, Byrum B (2014b) Development and evaluation of a duplex real-time RT-PCR for detection and differentiation of virulent and variant strains of porcine epidemic diarrhea viruses from the United States. J Virol Methods 207:154-157. https://doi.org/10. 1016/j.jviromet.2014.07.005

Wen D, Liu G, Opriessnig T, Yang Z, Jiang Y (2019) Simultaneous detection of five pig viruses associated with enteric disease in pigs using EvaGreen real-time PCR combined with melting curve analysis. J Virol Methods 268:1-8. https://doi.org/10.1016/j.jviromet. 2019.03.001

Wesley RD, Woods RD, Hill HT, Biwer JD (1990) Evidence for a porcine respiratory coronavirus, antigenically similar to transmissible gastroenteritis virus, in the United States. J Vet Diagn Investig 2(4): 312-317. https://doi.org/10.1177/104063879000200411

Woo PC, Huang Y, Lau SK, Yuen KY (2010) Coronavirus genomics and bioinformatics analysis. Viruses 2(8):1804-1820. https://doi.org/10. 3390/v2081803

Woo PC, Lau SK, Lam CS, Lau CC, Tsang AK, Lau JH, Bai R, Teng JL, Tsang CC, Wang M, Zheng BJ, Chan KH, Yuen KY (2012) Discovery of seven novel Mammalian and avian coronaviruses in the genus deltacoronavirus supports bat coronaviruses as the gene source of alphacoronavirus and betacoronavirus and avian coronaviruses as the gene source of gammacoronavirus and deltacoronavirus. J Virol 86(7):3995-4008. https://doi.org/10. 1128/jvi.06540-11

Xing N, Guan X, An B, Cui B, Wang Z, Wang X, Zhang X, Du Q, Zhao X, Huang Y, Tong D (2016) Ultrasensitive detection of porcine epidemic diarrhea virus from fecal samples using functionalized 
nanoparticles. PLoS One 11(12):e0167325. https://doi.org/10.1371/ journal.pone. 0167325

Yang DQ, Ge FF, Ju HB, Wang J, Liu J, Ning K, Liu PH, Zhou JP, Sun QY (2014) Whole-genome analysis of porcine epidemic diarrhea virus (PEDV) from eastern China. Arch Virol 159(10):2777-2785. https://doi.org/10.1007/s00705-014-2102-7

Yang X, Huo JY, Chen L, Zheng FM, Chang HT, Zhao J, Wang XW, Wang CQ (2013) Genetic variation analysis of reemerging porcine epidemic diarrhea virus prevailing in central China from 2010 to 2011. Virus Genes 46(2):337-344. https://doi.org/10.1007/s11262012-0867-x

Yuan W, Li Y, Li P, Song Q, Li L, Sun J (2015) Development of a nanoparticle-assisted PCR assay for detection of porcine epidemic diarrhea virus. J Virol Methods 220:18-20. https://doi.org/10.1016/ j.jviromet.2015.04.008

Zhang J (2016) Porcine deltacoronavirus: overview of infection dynamics, diagnostic methods, prevalence and genetic evolution. Virus Res 226:71-84. https://doi.org/10.1016/j.virusres.2016.05.028

Zhang J, Tsai YL, Lee PY, Chen Q, Zhang Y, Chiang CJ, Shen YH, Li FC, Chang HF, Gauger PC, Harmon KM, Wang HT (2016) Evaluation of two singleplex reverse transcription-Insulated isothermal PCR tests and a duplex real-time RT-PCR test for the detection of porcine epidemic diarrhea virus and porcine deltacoronavirus. J Virol Methods 234:34-42. https://doi.org/10.1016/j.jviromet.2016. 03.016

Zhao J, Shi BJ, Huang XG, Peng MY, Zhang XM, He DN, Pang R, Zhou B, Chen PY (2013) A multiplex RT-PCR assay for rapid and differential diagnosis of four porcine diarrhea associated viruses in field samples from pig farms in East China from 2010 to 2012. J Virol Methods 194(1-2):107-112. https://doi.org/10.1016/j.jviromet. 2013.08.008

Zhao PD, Bai J, Jiang P, Tang TS, Li Y, Tan C, Shi X (2014) Development of a multiplex TaqMan probe-based real-time PCR for discrimination of variant and classical porcine epidemic diarrhea virus. J Virol Methods 206:150-155. https://doi.org/10.1016/j. jviromet.2014.06.006

Zhou L, Sun Y, Wu JL, Mai KJ, Chen GH, Wu ZX, Bai Y, Li D, Zhou ZH, Cheng J, Wu RT, Zhang XB, Ma JY (2018) Development of a TaqMan-based real-time RT-PCR assay for the detection of SADS$\mathrm{CoV}$ associated with severe diarrhea disease in pigs. J Virol Methods 255:66-70. https://doi.org/10.1016/j.jviromet.2018.02. 002

Zhou X, Zhang T, Song D, Huang T, Peng Q, Chen Y, Li A, Zhang F, Wu Q, Ye Y, Tang Y (2017) Comparison and evaluation of conventional RT-PCR, SYBR green I and TaqMan real-time RT-PCR assays for the detection of porcine epidemic diarrhea virus. Mol Cell Probes 33:36-41. https://doi.org/10.1016/j.mcp.2017.02.002

Zhu X, Wang Y, Chen J, Zhang X, Shi H, Shi D, Gao J, Feng L (2016a) Development of TaqMan real-time reverse transcription-polymerase chain reaction for the detection and quantitation of porcine kobuvirus. J Virol Methods 234:132-136. https://doi.org/10.1016/ j.jviromet.2016.01.016

Zhu Y, Liang L, Luo Y, Wang G, Wang C, Cui Y, Ai X, Cui S (2017) A sensitive duplex nanoparticle-assisted PCR assay for identifying porcine epidemic diarrhea virus and porcine transmissible gastroenteritis virus from clinical specimens. Virus Genes 53(1):71-76. https://doi.org/10.1007/s11262-016-1405-z

Zhu Y, Wang GH, Cui YD, Cui SJ (2016b) Establishment of a nanoparticle-assisted RT-PCR assay to distinguish field strains and attenuated strains of porcine epidemic diarrhea virus. Arch Virol 161(9):2543-2547. https://doi.org/10.1007/s00705-016-2918-4

Publisher's note Springer Nature remains neutral with regard to jurisdictional claims in published maps and institutional affiliations. 